Check for updates

Cite this: RSC Adv., 2019, 9, 26136

Received 17th June 2019

Accepted 14th August 2019

DOI: $10.1039 / c 9 r a 04535 j$

rsc.li/rsc-advances

\title{
Performance of selenate removal by biochar embedded nano zero-valent iron and the biological toxicity to Escherichia coli $\uparrow$
}

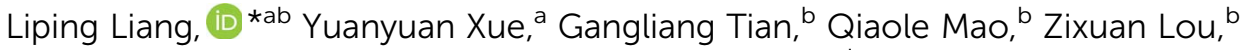 \\ Qian Wu, ${ }^{a}$ Qian Wang, ${ }^{a}$ Juanshan $\mathrm{Du}^{\mathrm{c}}$ and Xu Meng ${ }^{\star d}$
}

\begin{abstract}
The application of nano zero-valent iron ( $\mathrm{nZVI}$ ) in water environment was limited by its easily aggregation and potential biological toxicity. In this study, biochar embedded nZVI (BC-nZVI) was prepared by carbonthermal reduction method, and the SEM-EDX mapping results showed that nZVI was successfully embedded on biochar. Meanwhile, BC-nZVI with the optimal Fe/C of 2/1 showed a similar Se(vi) removal efficiency to pure nZVI. Effects of $\mathrm{pH}, \mathrm{BC}-\mathrm{nZVI}$ loading, and initial Se(VI) concentration were studied. Se(vi) removal rates (at $30 \mathrm{~min}$ ) by BC-nZVI at pH 4.0 and 5.0 were $98.2 \%$ and $95.9 \%$, respectively. But Se(vi) removal rate (at $30 \mathrm{~min}$ ) was sharply decreased to $25.8 \%$ at $\mathrm{pH}$ 6.0. With the increase of BC-nZVI loading from $0.5 \mathrm{~g} \mathrm{~L}^{-1}$ to $1 \mathrm{~g} \mathrm{~L}^{-1}$, Se(v) removal rate (at $30 \mathrm{~min}$ ) significantly increased from $25.5 \%$ to 95.9\%. And the continuous increase of BC-nZVI loading to $2 \mathrm{~g} \mathrm{~L}^{-1}$ did not improve Se(vi) removal rate. Se(vI) less than $3 \mathrm{mg} \mathrm{L}^{-1}$ was completely removed by BC-nZVI in $30 \mathrm{~min}$, but Se(vI) more than $6 \mathrm{mg} \mathrm{L}^{-1}$ only was removed about $25.9 \%$ at $30 \mathrm{~min}$. Optimal parameters were $\mathrm{pH} 4.0,2 \mathrm{~g} \mathrm{~L}^{-1} \mathrm{BC}-\mathrm{nZVI}$, and $1.5 \mathrm{mg} \mathrm{L}^{-1} \mathrm{Se}(\mathrm{VI})$. Variation of calculated amount, SOD activity, and protein content of Escherichia coli with $n Z V I$ and $B C-n Z V I$ indicated that $n Z V I$ and $B C-n Z V I$ both produced negative effects on the growth of E. coli. But the amount and SOD activity of E. coli with pure nZVI was lower than that with BC-nZVI. Moreover, E. coli with $n Z V I$ released more protein than that with BC-nZVI. So modified $n Z V I$ by biochar was less harmful to $E$. coli than $n Z V I$.
\end{abstract}

\section{Introduction}

Selenium (Se) as a non-metallic element is very important to immune systems of human, animals, and plants. The supplement of Se may boost immunity and prevent myelopathy such as Keshan disease, ${ }^{1}$ Kashin-Beck disease, ${ }^{2}$ and rheumatoid arthritis. $^{3}$ And recommended daily Se intakes are 30-40 $\mu \mathrm{g} \mathrm{d}^{-1}$ in China, and 11-70 $\mu \mathrm{g} \mathrm{d}^{-1}$ in some European countries. ${ }^{4}$ But excess Se $\left(>400 \mu \mathrm{g} \mathrm{d}^{-1}\right)$ is harmful to organisms. ${ }^{5}$ In addition, Se and Se compounds have been listed in IRAC group 3 since $1987 . .^{6}$ Sources of Se in water environment mainly include natural processes ${ }^{7}$ via storm water runoff, inflow, or infiltration from mining operations and arid soils, ${ }^{8}$ the use of chemicals or medicines containing $\mathrm{Se}^{9}$ such as herbicides, insecticides, anti-

${ }^{a}$ School of Civil Engineering, Shaoxing University, Shaoxing 312000, P. R. China. E-mail: Liangliping0702@163.com; Tel: +86-575-88345007

${ }^{b}$ College of Life Science, Shaoxing University, Shaoxing 312000, P. R. China

'State Key Laboratory of Urban Water Resource and Environment, Harbin Institute of Technology, Harbin 150090, PR China

${ }^{d}$ College of Textile and Garment, Shaoxing University, Shaoxing 312000, P. R. China. E-mail: mengxu0@163.com; Tel: +86-575-88341506

$\dagger$ Electronic supplementary information (ESI) available. See DOI: $10.1039 / \mathrm{c} 9 \mathrm{ra} 04535 \mathrm{j}$ fungal medicines, and anti-dandruff shampoos, ${ }^{7}$ and industrial wastewater ${ }^{10}$ of electronics, petroleum refining, oxidation of sulfide minerals, and copper smelting. ${ }^{4}$ Concentrations of Se contaminations in various industrial wastewater resources reach $\mathrm{mg} \mathrm{\textrm {L } ^ { - 1 } , 1 1}$ and average selenium concentration in groundwater ranges from $\mathrm{ng} \mathrm{L} \mathrm{L}^{-1}$ to $\mu \mathrm{g} \mathrm{L}^{-1}{ }^{12}$ The maximum contamination level of Se in drinking water has been set at 10, 40 , and $50 \mu \mathrm{g} \mathrm{L}^{-1}$ by European Union, ${ }^{13} \mathrm{WHO}^{14}$ (World Health Organization), and the USA, ${ }^{15}$ respectively. Therefore, Se contamination in water has attracted a widespread concern and studies on Se removal from aquatic environment would be necessary.

Generally, element Se exists in various valence states and form including selenide ( $\mathrm{Se}(\mathrm{II}))$, elemental Se $(\mathrm{Se}(0))$, selenite $(\mathrm{Se}(\mathrm{Iv}))$, selenate $(\mathrm{Se}(\mathrm{vI}))$, and several organic selenium compounds such as selenomethionine and dimethyl selenide. $\mathrm{Se}(\mathrm{vI})$ and $\mathrm{Se}(\mathrm{Iv})$, as main species of Se in water, possesses high solubility, bioavailability, and toxicity. ${ }^{16}$ Although the acute toxicity of $\mathrm{Se}(\mathrm{rv})$ is much higher than that of $\mathrm{Se}(\mathrm{vI})$, the conversion between $\mathrm{Se}(\mathrm{vI})$ and $\mathrm{Se}(\mathrm{Iv})$ might occur in aerobic or anaerobic environment. So Se(vi) and Se(Iv) might coexist in anaerobic water in comparable concentrations. ${ }^{17} \mathrm{Se}(\mathrm{Iv})$ can be more easily absorbed by iron oxide than $\mathrm{Se}(\mathrm{vI})$, and $\mathrm{Se}(\mathrm{vI})$ with high transfer ability in water is more harmful to various aquatic lives and 
human. Therefore, it is necessary to develop efficient strategies to remove $\mathrm{Se}(\mathrm{vi})$ from water environment.

Compared to $\mathrm{Se}(\mathrm{vI})$ removal technologies such as microbiological reduction, chemical coagulation, ion exchange, and reverse osmosis, zero valent iron (ZVI) exhibits more advances in $\mathrm{Se}(\mathrm{vI})$ removal for its low cost, easy handling, and ready availability. ZVI as a moderately strong reducing agent could directly reduce $\mathrm{Se}(\mathrm{vI})$ to $\mathrm{Se}(\mathrm{Iv})$ or $\mathrm{Se}(0)$, and new generated $\mathrm{Se}(\mathrm{Iv})$ can be reduced to $\mathrm{Se}(0)$ by ZVI or new generated $\mathrm{Fe}(\mathrm{II})$ on ZVI surface. ${ }^{18,19}$ Furthermore, Se(Iv) or $\mathrm{Se}(0)$ can also be absorbed or co-precipitated by iron oxides or hydroxides generated during the corrosion of ZVI. Thus, Se(vI) can be completely removed by $\mathrm{ZVI} / \mathrm{H}_{2} \mathrm{O}$ systems via reduction, absorption, and coprecipitation. But ZVI in the form of iron turning or powder always exhibits a low reactivity towards contaminants for its low specific surface area. The synthesis of nano ZVI (nZVI) can extensively improve the reactivity of ZVI, and enhances the performance of contaminants removal. ${ }^{20}$ And many studies of the removal of heavy metals, halogenated organics, and dyes by nZVI have been reported. ${ }^{21}$ Although nZVI shows more excellent reactivity than micro iron power or iron turning, the safety and aggregation of aquatic nZVI limited the engineering application of nZVI in water treatment. ${ }^{22}$ In particular, the ecotoxicity of nZVI has aroused many researchers' concern. Lee et al. ${ }^{23}$ reported that nZVI in water could rapidly inactivated Escherichia coli $(E$. coli), and the bactericidal effect was also observed in other types of iron based compounds. ${ }^{24}$ El-Temsah and Joner ${ }^{25}$ stated that nZVI had acute adverse effects on earthworms and aged or oxidized nZVI could decrease its toxicity to earthworms. Zhou et al. ${ }^{26}$ found that nZVI generated reactive oxygen species (ROS) to discharge mitigated obviously the membrane fouling of MBR. Thus the potential ecotoxicity of nZVI should be evaluated during $\mathrm{Se}(\mathrm{vI})$ removal to increase the potentiality of nZVI in application. Carbon materials were an ideal carrier of nZVI for its stability, high mechanical strength, and good conductivity. ${ }^{27}$ So the synthesis of biochar embedded nZVI (BC-nZVI) might reduce the aggregation and ecotoxicity of nZVI. ${ }^{28}$ But few researches study $\mathrm{Se}(\mathrm{vI})$ removal by BC-nZVI and the biological toxicity of BC-nZVI is still unclear.

Thus, the objectives of this study were to (1) characterize nZVI and BC-nZVI samples, (2) investigate optimal proportion of iron and carbon (Fe/C) of BC-nZVI, (3) study different solution factors on $\mathrm{Se}(\mathrm{vI})$ removal by BC-nZVI, and (4) evaluate biological toxicity of BC-nZVI and nZVI to E. coli.

\section{Experimental}

\section{Reagent}

Ferrous sulfate, sodium borohydride purchased from Sinopharm Chemical Reagent Co., Ltd. (Shanghai, China) were of analytical grade. Biochar were made by peanut shell at $500{ }^{\circ} \mathrm{C}$. (Particle size distribution and elemental analysis of biochar are shown in Fig. $\mathrm{S} 1$ and Table $\mathrm{S} 1, \uparrow$ respectively.) Sodium selenate was supplied by Sigma-Aldrich Co. LLC. (St. Louis, USA). Other chemicals used in this study were obtained from Shanghai Qiangshun Chemical Reagent Company (Shanghai, China). Stock solutions were dissolved in DI (de-ionized) water.

\section{Synthesis of nZVI and BC-nZVI}

The BC-nZVI was prepared by carbo-thermal reduction method. Firstly, $\mathrm{N}_{2}$ was purged into $140 \mathrm{~mL}$ deionized water for $30 \mathrm{~min}$ in a $500 \mathrm{~mL}$ three-necked flask. Then a definite amount of $\mathrm{FeSO}_{4} \cdot 7 \mathrm{H}_{2} \mathrm{O}$ and $35 \mathrm{~mL}$ ethanol was added into the flask. And a fixed proportion of biochar was mixed and continuously stirred by a magnetic stirrer at $200 \mathrm{rpm}$. After $1 \mathrm{~h}, 50 \mathrm{~mL} \mathrm{NaBH}$ $\left(50 \mathrm{~g} \mathrm{~L}^{-1}\right)$ was added into the above solution at a uniform rate of 1-2 drops per second under the protection of $\mathrm{N}_{2}$. After aging for $1 \mathrm{~h}, \mathrm{BC}-\mathrm{nZVI}$ was washed a number of times with deoxygenated DI water and ethanol under the protection of $\mathrm{N}_{2}$. Finally, BCnZVI was sealed after freeze-drying and stored in anaerobic conditions. Meanwhile, nZVI was also prepared by the above procedure but without adding biochar.

\section{Kinetics experiments}

Batch experiments were conducted to investigate removal kinetics of Se(vI) by nZVI and BC-nZVI in a wild-mouth glass reactor open to the air at $20 \pm 1.0^{\circ} \mathrm{C}$ controlled by thermostatic bath. $0.5 \mathrm{~L}$ solution containing $\mathrm{Se}(\mathrm{vI})$ was completely mixed by digital display electric blender at $300 \mathrm{rpm}$. The solution $\mathrm{pH}$ value was buffered by $0.1 \mathrm{M} \mathrm{NaAc}$ and $\mathrm{HAc}$ at $\mathrm{pH} 4.0$ and 5.0, the $\mathrm{pH}$ value of 6.0 was buffered by $0.1 \mathrm{M}$ MES. And a certain amount of nZVI was quickly added into solution to initial experiments. At fixed interval time, about $5 \mathrm{~mL}$ sample was quickly filtered with $0.22 \mu \mathrm{m}$ membrane samples and placed in the PTFE tubule which contained 1 drop of $65 \%$ concentrated nitric acid, and the final pH of all samples were below 2.0. All kinetics experiments were run in duplicates. The solid sample after reaction were collected, washed with DI water and freeze dried for further analysis.

\section{Biological toxicity experiments}

The quantity and morphological changes of $E$. coli were observed after culture with BC-nZVI or nZVI. The supernatant of the treated culture solution was collected by centrifugation at different time intervals. Variation of protein and superoxide dismutase (SOD) in cells were monitored to study effects of BCnZVI or nZVI on the cell activity of $E$. coli.

\section{Chemical analysis}

A laboratory Shanghai Leici pHS-3C pH meter (Shanghai, China) was used to monitor $\mathrm{pH}$ value. The morphological analysis of nZVI, biochar, and BC-nZVI samples were performed by a JEOL JEM-1011 transmission electron microscopy (TEM) (Tokyo, Japan), a FEI Quanta 600 scanning electron microscopy (SEM) (Eindhoven, the Netherlands), and a Carl Zeiss SIGMA 300 SEM (Oberkochen, Germany), respectively. The morphological analysis of $E$. Coli cells were performed by a JEOL JEM1011 transmission electron microscopy (TEM) (Tokyo, Japan). The crystal morphology of nZVI samples were analyzed by Rigaku DXR-8000 X-ray diffraction (Tokyo, Japan). Concentrations of Fe(II) were measured at $510 \mathrm{~nm}$ by the Shimadzu UVvisible 2600 spectrophotometer (Kyoto, Japan). Standards containing known concentrations of ferrous ion were used as 
reference for each set of tests. Concentrations of Se(vI) in solution were measured by the PerkinElmer Optima 5300 DV ICPOES (Waltham, United States). Contents of protein and SOD in cells by Coomassie brilliant blue G250 and SOD kit.

\section{Results and discussion}

\section{Characterization of nZVI and BC-nZVI}

Fig. 1 shows the morphology images of synthesized nZVI (TEM), biochar (SEM), and BC-nZVI (Fe/C $=2 / 1$, SEM) samples. Synthesized nZVI exhibited thick chain structures for the aggregation of various spherical nZVI particles. Biochar had a complex net structure with pores, channels, and fibrous form which might easily embed the nZVI. SEM-EDS elemental mapping results of $\mathrm{C}$ (red), $\mathrm{Fe}$ (orange) and $\mathrm{O}$ (green) of BC-nZVI are illustrated in Fig. S2, $\dagger$ and it clearly showed the nZVI was uniformly embedded on the biochar. BET specific surface area (SSA) was an important parameter of characterizing nZVI reactivity. The SSA of the synthesized nZVI reached $160 \mathrm{~m}^{2} \mathrm{~g}^{-1}$, but the SSA of BC-nZVI decreased to $108 \mathrm{~m}^{2} \mathrm{~g}^{-1}$. Generally, nZVI with a lager SSA showed a higher reactivity towards contaminants. Thus the addition of biochar could reduce the reactivity of nZVI. The XRD patterns of unreacted nZVI and BC-nZVI are both represented in Fig. 2 . The synthesized nZVI was mainly in its $\mathrm{Fe}^{0}$ state (PDF06-0696). Meanwhile the diffraction peak of $\mathrm{Fe}_{2} \mathrm{O}_{3}$ (PDF39-1346) also was detected in nZVI which indicated that part of nZVI might be oxidised during the synthesis of nZVI. The synthesized BC-nZVI could form lepidocrocite (PDF08-0098), but no iron oxide was detected in BC-nZVI samples which indicated that the addition of biochar changed the iron oxide type on nZVI surface.

\section{Effects of different ratio of $\mathrm{Fe} / \mathrm{C}$ on $\mathrm{Se}(\mathrm{vI})$ removal by BC-nZVI}

In order to optimal the $\mathrm{Fe} / \mathrm{C}$ of $\mathrm{BC}-\mathrm{nZVI}$ materials for $\mathrm{Se}(\mathrm{vI})$ removal, effects of BC-nZVI with different $\mathrm{Fe} / \mathrm{C}$ of $1 / 1,2 / 1,7 / 1$
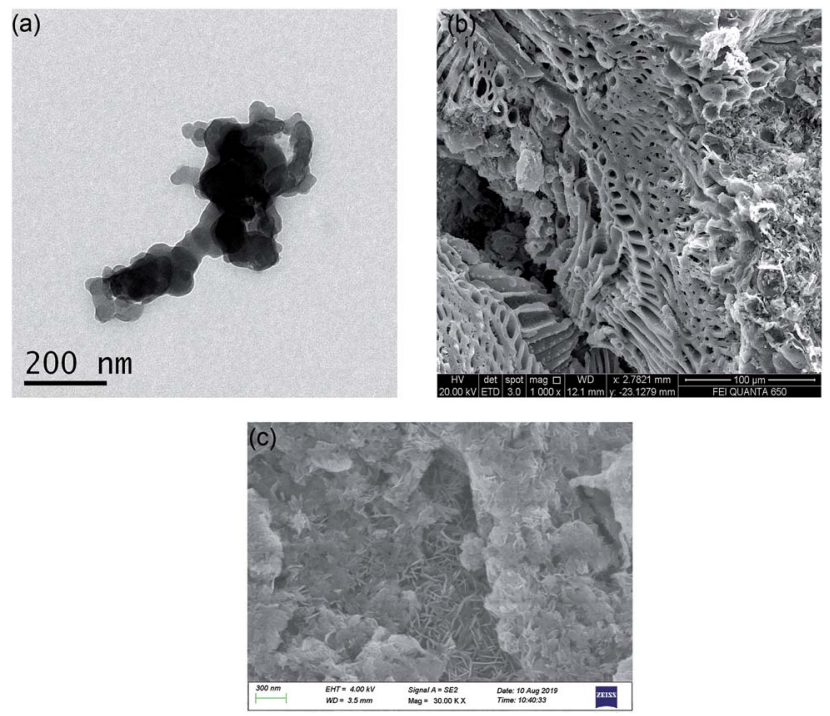

Fig. 1 Morphology images of nZVI (a), biochar (b), and BC-nZVI (Fe/C $=2 / 1)(\mathrm{c})$.

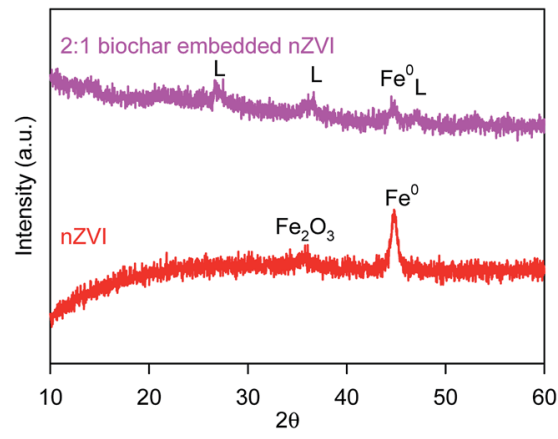

Fig. 2 XRD patterns of $n Z V I$ and $B C-n Z V I(F e / C$ of $2 / 1)$ before reaction.

and nZVI on Se(vi) removal were compared experimentally. As shown in Fig. 3a, few Se(vi) was removed within $120 \mathrm{~min}$ by $1.0 \mathrm{~g}$ $\mathrm{L}^{-1}$ biochar alone. Generally biochar as carbon-based materials might absorb contaminants, but $\mathrm{Se}(\mathrm{vI})$ was hardly to be absorbed which indicated that $\mathrm{Se}(\mathrm{vI})$ showed a strong resistance to biochar. Nevertheless, Se(vI) was easily to be removed by nZVI, and the removal rate of $\mathrm{Se}(\mathrm{vI})$ was more than $95.4 \%$ in $30 \mathrm{~min}$. Effects of three BC-nZVI samples on $\mathrm{Se}(\mathrm{vI})$ removal also were investigated. With the increase of $\mathrm{Fe} / \mathrm{C}$ from $1 / 1$ to $2 / 1$, the removal rate of $\mathrm{Se}(\mathrm{vI})$ at $30 \mathrm{~min}$ increased from $48.8 \%$ to $95.9 \%$. But the removal rate of $\mathrm{Se}(\mathrm{vI})$ at $30 \mathrm{~min}$ decreased to $59.5 \%$ when $\mathrm{Fe} / \mathrm{C}$ reached to $7 / 1$. On the one hand, the participation of $\mathrm{nZVI}$ in biochar materials could extensively enhance $\mathrm{Se}(\mathrm{vI})$ removal. On the other hand, the reactivity of BC-nZVI towards $\mathrm{Se}(\mathrm{vI})$ might be lower than pure nZVI. But the removal rate of Se(vI) by BC-nZVI with the optimal Fe/C of $2 / 1$ at 30 min was similar to

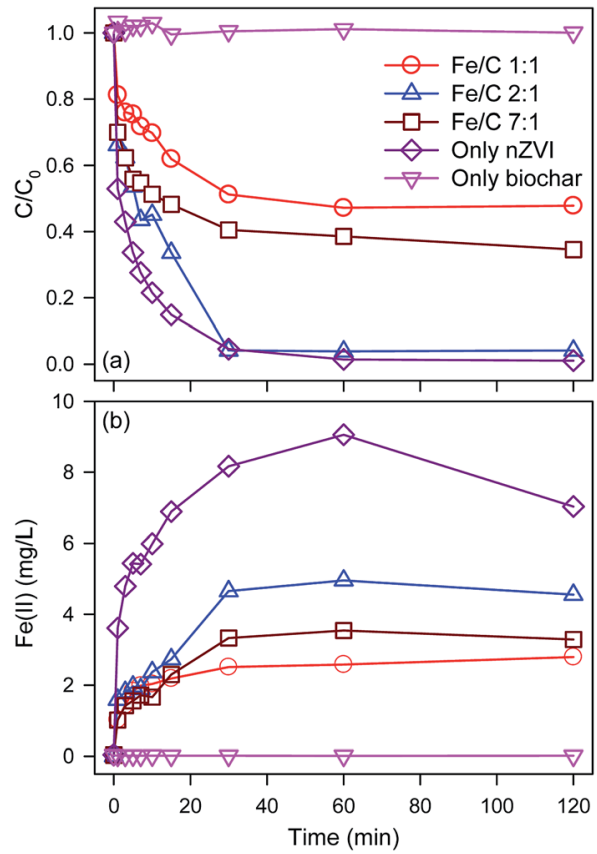

Fig. 3 Kinetics of $\mathrm{Se}(\mathrm{VI})$ removal (a) and $\mathrm{Fe}(\mathrm{I})$ release during $\mathrm{Se}(\mathrm{VI})$ removal (b) by biochar, $\mathrm{BC}-\mathrm{nZVI}$, and $\mathrm{nZVI}$ with different $\mathrm{Fe} / \mathrm{C}$. Experiment conditions: $[\mathrm{Se}(\mathrm{IV})]_{0}=3.0 \mathrm{mg} \mathrm{L}^{-1}$, [biochar $]=[\mathrm{BC}-\mathrm{nZVI}]=$ $[\mathrm{nZVI}]=1.0 \mathrm{~g} \mathrm{~L}^{-1}$, and $\mathrm{pH}=5.0$. 


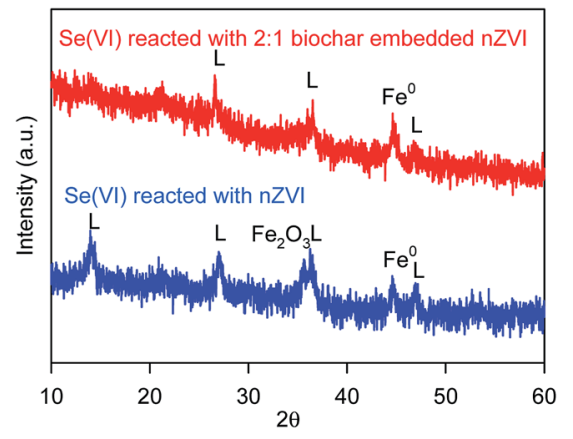

Fig. 4 XRD patterns of $n Z V I$ and $B C-n Z V I(F e / C$ of $2 / 1)$ after reaction.

that by pure nZVI. So the replacement of part nZVI by biochar might enhance the reactivity of nZVI towards Se(vi). Generally, the release rate of $\mathrm{Fe}(\mathrm{II})$ represented the real reactivity of nZVI in water. Thus release kinetics of $\mathrm{Fe}(\mathrm{II})$ during $\mathrm{Se}(\mathrm{VI})$ removal are also monitored and shown in Fig. 3b. Fe(II) was quickly released with the degradation of $\mathrm{Se}(\mathrm{VI})$, and the release rate of $\mathrm{Fe}(\mathrm{II})$ during $\mathrm{Se}(\mathrm{vI})$ removal by various materials was consistent with the removal rate of $\mathrm{Se}(\mathrm{vI})$ which indicated that the removal of $\mathrm{Se}(\mathrm{vI})$ was ascribe to the corrosion of nZVI. Of three BC-nZVI, the BC-nZVI with the optimal $\mathrm{Fe} / \mathrm{C}$ of $2 / 1$ exhibited the highest release rate of $\mathrm{Fe}(\mathrm{II})$. Thus, $\mathrm{BC}-\mathrm{nZVI}$ with $\mathrm{Fe} / \mathrm{C}$ of $2 / 1$ did not limit the reactivity towards $\mathrm{Se}(\mathrm{VI})$ but decreased the release of $\mathrm{Fe}$ (II) which reduced the discharge of residual sludge in engineering. The XRD patterns of nZVI and BC-nZVI (Fe/C of 2/1) samples after $\mathrm{Se}(\mathrm{vI})$ removal are both represented in Fig. 4 . The results of XRD indicated the generation of lepidocrocite $(\gamma-\mathrm{FeOOH})$ (PDF08-0098) after $120 \mathrm{~min}$ reaction with $\mathrm{Se}(\mathrm{vI})$. Other studies $^{29,30}$ also identified that lepidocrocite was the first corrosion product in aerobic water. Besides, iron corrosion products of BC-nZVI after the reaction with Se(vI) were mainly lepidocrocite. Thus, the modification of nZVI by biochar did not change the corrosion process of BC-nZVI during Se(vI) removal.

\section{Effects of key factors}

BC-nZVI with the optimal Fe/C of $2 / 1$ was selected to study effects of different factors on $\mathrm{Se}(\mathrm{vI})$ removal, and optimal experimental conditions were obtained. As shown in Fig. 5a, similar $\mathrm{Se}(\mathrm{vI})$ removal rate (at $30 \mathrm{~min}$ ) are found at $\mathrm{pH} 4.0$ $(98.2 \%)$ and $5.0(95.9 \%)$, but $\mathrm{Se}(\mathrm{vI})$ removal rate (at $30 \mathrm{~min}$ ) at pH 6.0 was only $25.8 \%$. Reactions between $\mathrm{Se}(\mathrm{vI})$ and nZVI needed the participation of $\mathrm{H}^{+}$, and acidic solution could facilitate Se(vi) removal. ${ }^{31}$ Meanwhile, low $\mathrm{pH}$ could also clean iron oxide layer on nZVI which generated during reactions. ${ }^{32}$ Solution $\mathrm{pH}$ increased for the consumption of $\mathrm{H}^{+}$as the reaction progress, and the removal rate of $\mathrm{Se}(\mathrm{vI})$ might be inhibited. Effects of $\mathrm{pH}$ on the release of $\mathrm{Fe}(\mathrm{II})$ during $\mathrm{Se}(\mathrm{VI})$ removal are monitored in Fig. 5b. With pH increased from 4.0 to 6.0 , the released rate of $\mathrm{Fe}(\mathrm{II})$ deceased. Curiously, the release rate of $\mathrm{Fe}(\mathrm{II})$ at $\mathrm{pH} 4.0$ was much higher than that at $\mathrm{pH}$ 5.0, however there are no difference of $\mathrm{Se}(\mathrm{vI})$ removal rate at $\mathrm{pH}$ values between 4.0 and 5.0. The excessive release of $\mathrm{Fe}(\mathrm{II})$ at $\mathrm{pH} 4.0 \mathrm{did}$ not promote the removal of $\mathrm{Se}(\mathrm{vI})$. The acid solution competed more reactivity sites of nZVI with $\mathrm{Se}(\mathrm{vI})$ during $\mathrm{Se}(\mathrm{vI})$ removal to generate more Fe(II). So pH 5.0 was selected as the solution $\mathrm{pH}$ for study effects of other factors on $\mathrm{Se}(\mathrm{vI})$ removal to obtain higher $\mathrm{Se}(\mathrm{vI})$ removal rate and decrease the generation of residual iron sludge.

Fig. $5 c$ shows effects of BC-nZVI loading on the removal of $\mathrm{Se}(\mathrm{vI})$. With the increase of BC-nZVI loading from $0.5 \mathrm{~g} \mathrm{~L}^{-1}$ to $1 \mathrm{~g}$ $\mathrm{L}^{-1}$, the removal rate of $\mathrm{Se}(\mathrm{VI})$ at $30 \mathrm{~min}$ significantly increased from $25.5 \%$ to $95.9 \%$. Generally, the increase of BC-nZVI could provide more surface active sites, which leaded to the promotion of Se(vI) removal rate. The increasing BC-nZVI loading from
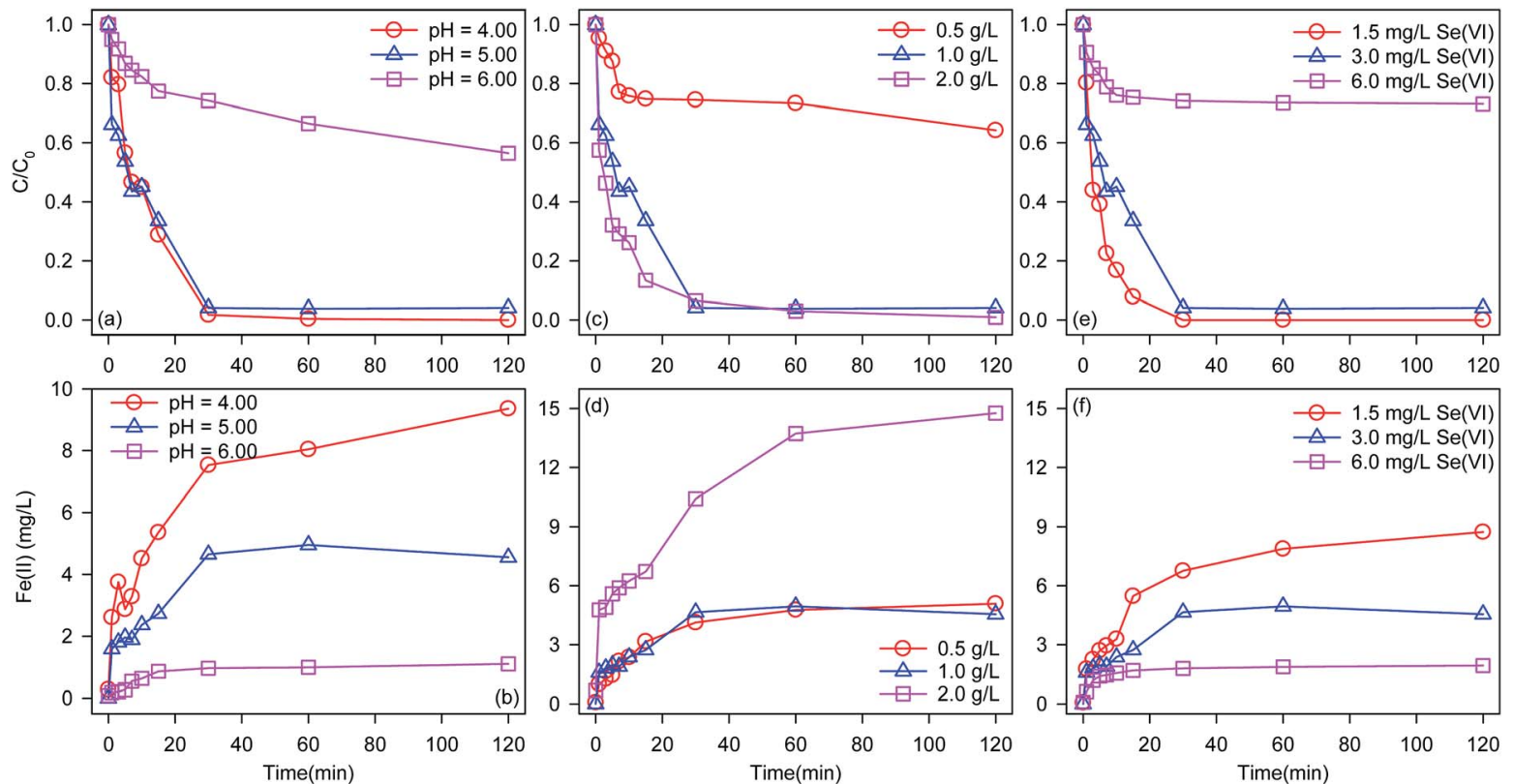

Fig. 5 Effects of pH, BC-nZVI loading, initial Se(VI) concentration and Fe(॥) release during Se(vI) removal by BC-nZVI. Experiment conditions: $[\mathrm{Se}(\mathrm{IV})]_{0}=3.0 \mathrm{mg} \mathrm{L}^{-1}(\mathrm{a}-\mathrm{d})$, [biochar $]=[\mathrm{BC}-\mathrm{nZVI}]=[\mathrm{nZVI}]=1.0 \mathrm{~g} \mathrm{~L}^{-1}(\mathrm{a}, \mathrm{b}, \mathrm{e}$, and f), and $\mathrm{pH}=5.0$ (c-f). 
$1 \mathrm{~g} \mathrm{~L}^{-1}$ to $2 \mathrm{~g} \mathrm{~L}^{-1}$ slightly increased the removal rate of $\mathrm{Se}(\mathrm{vI})$ which indicated that surface active sites of $1 \mathrm{~g} \mathrm{~L}^{-1} \mathrm{BC}-\mathrm{nZVI}$ were enough to remove $\mathrm{Se}(\mathrm{vI})$, and the continuous increase of $\mathrm{BC}$ nZVI could not improve the removal rate of $\mathrm{Se}(\mathrm{vI})$.

As shown in Fig. 5d, the increase of BC-nZVI loading from $0.5 \mathrm{~g} \mathrm{~L}^{-1}$ to $1 \mathrm{~g} \mathrm{~L}^{-1}$ can accelerate the release of $\mathrm{Fe}(\mathrm{II})$. But the release of $\mathrm{Fe}(\mathrm{II})$ during $\mathrm{Se}(\mathrm{VI})$ removal by $1 \mathrm{~g} \mathrm{~L}^{-1}$ BC-nZVI was similar to that by $2 \mathrm{~g} \mathrm{~L}^{-1} \mathrm{BC}-\mathrm{nZVI}$, which indicated that the corrosion of nZVI was not promoted with the increase of BCnZVI loading.

Effects of initial Se(vI) concentration on the removal of Se(vI) are illustrated in Fig. 5e. With the decrease of $\mathrm{Se}(\mathrm{vI})$ concentration, the removal rate of $\mathrm{Se}(\mathrm{vI})$ increased. When the initial $\mathrm{Se}(\mathrm{vI})$ concentration was lower than $3 \mathrm{mg} \mathrm{L}^{-1}$, Se(vi) was completely removed by BC-nZVI in $30 \mathrm{~min}$. But the initial Se(vI) concentration reached to $6 \mathrm{mg} \mathrm{L}^{-1}$, the removal rate of Se(vI) at $30 \mathrm{~min}$ decreased to $25.9 \%$. Reactive sites of BC-nZVI were limited, and the increasing $\mathrm{Se}(\mathrm{vI})$ decreased the removal rate of $\mathrm{Se}(\mathrm{vI})$. Meanwhile, the remarkable decline of $\mathrm{Se}(\mathrm{vI})$ removal rate indicated that high $\mathrm{Se}(\mathrm{vI})$ concentration might inhibited the reactivity of BC-nZVI. Fig. $5 \mathrm{f}$ exhibits release kinetics of $\mathrm{Fe}(\mathrm{II})$ during $\mathrm{Se}(\mathrm{VI})$ removal. The release rate of $\mathrm{Fe}(\mathrm{II})$ increased with the decrease of initial Se(vi) concentration which indicated that the corrosion of nZVI was in accordance with Se(vi) removal.

\section{Biological toxicity of BC-nZVI to $E$. coli}

Researchers reported that nZVI could exhibit the bactericidal effect on E. coli. ${ }^{23}$ Fig. 6 shows the TEM images of $E$. coli in the absence and presence of nZVI, and nZVI could rupture or deform E. coli cells. Meanwhile, BC-nZVI contain nZVI which could also destroy $E$. coli cells. To study the biological adverse effect of BC-nZVI, E. coli was selected as the model microorganism to investigate the potential toxicity of BC-nZVI. Comparative experiments in the growth of $E$. coli cells with nZVI and BC-nZVI at different loadings were conducted. As shown in Fig. 7a, the amount of $E$. coli cells gradually decreased with the increasing loading of nZVI and BC-nZVI in the range of 0-6 $\mathrm{g} \mathrm{L}^{-1}$. But the amount of $E$. coli cells treated by nZVI was lower than that treated by BC-nZVI at the same loading. To further study the toxicity of BC-nZVI, the SOD enzyme activity of $E$. coli cells was measured. Generally, the SOD activity represented the degree of intracellular lipid peroxidation and the ability to scavenge reactive oxygen species. As shown in Fig. 7b, the SOD activity of $E$. coli cells decreases with the increasing
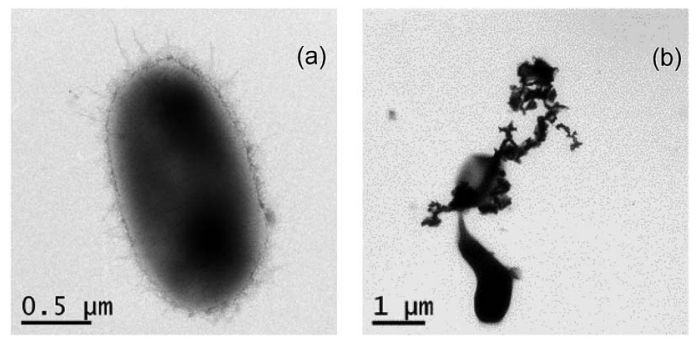

Fig. 6 TEM images of original E. coli (a) and E. coli treated by nZVI (b).
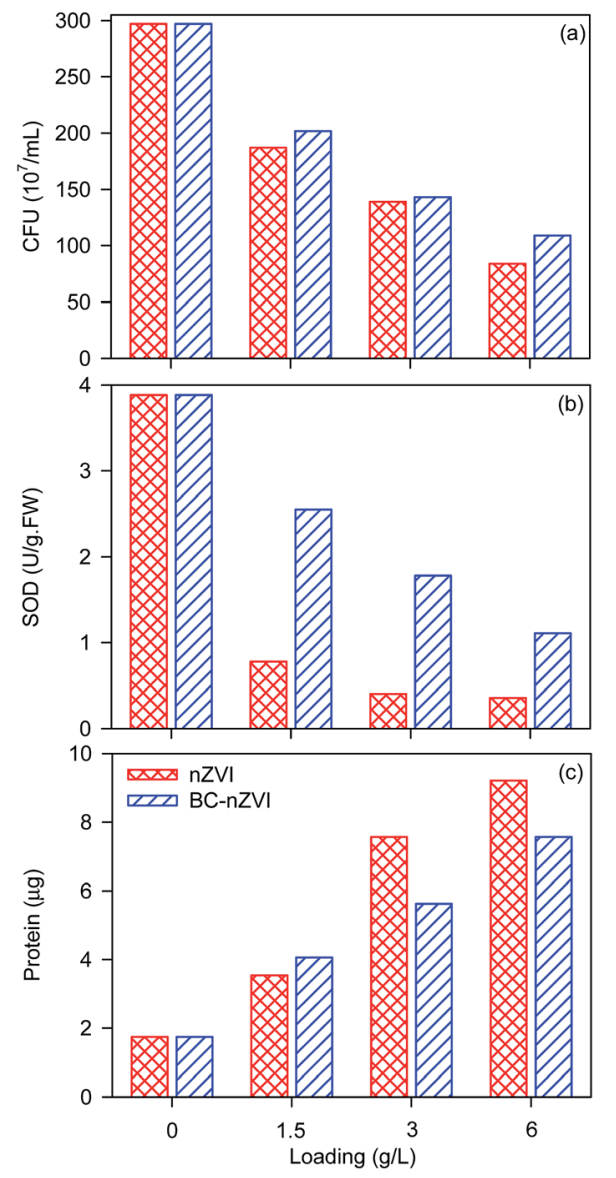

Fig. 7 Effects of $n Z V I$ and $B C-n Z V I$ with different loading on the calculated CFU of E. coli (a), the SOD activity of E. coli (b), and the protein generation during the growth of $E$. coli (c).

nZVI or BC-nZVI loading which is similar to the variation of $E$. coli amount. However, the SOD activity of $E$. coli cells with nZVI was much lower than that with BC-nZVI. Thus some $E$. coli cells in the presence of nZVI were survive but the activity of $E$. coli cells was seriously damaged. Meanwhile, Fig. 7c illustrates the content of the protein in $E$. coli culture medium. The content of the protein was quickly increased after the treatment of nZVI or BC-nZVI, which indicated that cells of $E$. coli were destroyed and intracellular organic matter were dissolved. And E. coli culture medium with nZVI could release more protein which suggested that nZVI possessed a higher ability to break up $E$. coli cells than BC-nZVI. So results of various biological indicator demonstrated that the biochar modification reduced destructive effects of nZVI on $E$. coli cells.

\section{Conclusions}

BC-nZVI with different Fe/C and pure nZVI were synthesized to remove aquatic $\mathrm{Se}(\mathrm{vI})$ removal. The SEM-EDX elemental mapping analysis showed that nZVI could be uniformly embedded on the carbon-thermal synthetic biochar. The addition of biochar decreased the SSA and formed lepidocrocite in BC-nZVI. BC-nZVI with Fe/C of 2/1 showed optimal removal rate by comparing other samples with different Fe/C. And pure 
biochar could hardly absorb $\mathrm{Se}(\mathrm{vI})$, so the removal of $\mathrm{Se}(\mathrm{vI})$ by BC-nZVI was contributed to nZVI. Effects of solution $\mathrm{pH}$, initial concentration of $\mathrm{Se}(\mathrm{vI})$, and BC-nZVI (Fe/C of 2/1) loading on $\mathrm{Se}(\mathrm{vI})$ removal were studied. And the optimal parameters were pH 4.0, $2 \mathrm{~g} \mathrm{~L}^{-1}$ BC-nZVI, and $1.5 \mathrm{mg} \mathrm{L}^{-1} \mathrm{Se}(\mathrm{vI})$. E. coli were employed to study the biological toxicity of BC-nZVI and pure nZVI. Quantitative results including calculated amount, SOD activity, and protein content of $E$. coli cells indicated that nZVI and BC-nZVI with different loading both inhibited the growth of $E$. coli. And the inhibition efficiency of $E$. coli cells growth increased with the increase of the loading of nZVI and BC-nZVI. But the amount of $E$. coli cells treated by nZVI was lower than that treated by BC-nZVI at the same loading. Moreover, the SOD activity of $E$. coli cells with nZVI was much lower than that with BC-nZVI. Some $E$. coli cells in the presence of pure nZVI might be survived but the activity of $E$. coli cells was seriously damaged. Meanwhile, $E$. coli culture solution with nZVI released more protein than that with BC-nZVI, which indicated that more intracellular organic matter of $E$. coli cells were dissolved in the presence of nZVI. So modified nZVI by biochar was less harmful to $E$. coli cells than nZVI.

\section{Conflicts of interest}

There are no conflicts to declare.

\section{Acknowledgements}

The authors gratefully acknowledge the financial support of the National Natural Science Foundation of China (Grant No. 41807468), Zhejiang Provincial Natural Science Foundation of China (Grant No. LY18E080018), Shaoxing Public Welfare Project (Grant No. 2017B70042), and National innovation and entrepreneurship training program for college students (Grant No. 201810349008) and University students' science and technology innovation program of Zhejiang Province (Young Talents Program) (Grant No. 2018R432004).

\section{Notes and references}

1 H. H. Zhou, T. Wang, Q. Li and D. D. Li, Biol. Trace Elem. Res., 2018, 186, 98-105.

2 L. H. Foster and S. Sumar, Crit. Rev. Food Sci. Nutr., 1997, 37, 211-228.

3 M. Sahebari, Z. Rezaieyazdi and M. Khodashahi, Curr. Rheumatol. Rev., 2019, 15, 123-134.

4 M. P. Rayman, The Lancet, 2000, 356, 233-241.

5 B. D. Gibson, D. W. Blowes, M. B. J. Lindsay and C. J. Ptacek, J. Hazard. Mater., 2012, 241-242, 92-100.

6 WHO, Agents Classified by the IARC Monographs, vol. 1-120, http://monographs.iarc.fr/ENG/Classification/ latest_classif.php.

7 D. Pontarolo, T. Sandy, N. Keller, M. Gearhart, V. Patel and J. Jimenez, Proceedings of the Water Environment Federation, 2017, 2017, 4118-4132.

8 J. T. Olegario, N. Yee, M. Miller, J. Sczepaniak and B. Manning, J. Nanopart. Res., 2009, 12, 2057-2068.
9 N. Bleiman and Y. G. Mishael, J. Hazard. Mater., 2010, 183, 590-595.

10 R. J. Shamberger, Sci. Total Environ., 1981, 17, 59-74.

11 P. Devi, R. Jain, A. Thakur, M. Kumar, N. K. Labhsetwar, M. Nayak and P. Kumar, Trends Anal. Chem., 2017, 95, 69-85. 12 S. Santos, G. Ungureanu, R. Boaventura and C. Botelho, Sci. Total Environ., 2015, 521-522, 246-260.

13 European Economic Community, Council Directive 98/83/ EC Relating to the Water Quality of Water Intended for Human Consumption, Off. J. Eur. Commun., 1998, L330, 32-54.

14 WHO, Guidelines for Drinking-water Quality, World Health Organization, Geneva, 4th edn, 2011.

15 USEPA, National Primary Drinking Water Regulations, List of Contaminants and their (MCLS), EPA 816-F-09-0004, United states Environmental Protection Agency, Washington, DC, 2009.

16 Y. Zhang, C. Amrhein, A. Chang and W. T. Frankenberger, Sci. Total Environ., 2008, 407, 89-96.

17 R. López de Arroyabe Loyo, S. I. Nikitenko, A. C. Scheinost and M. Simonoff, Environ. Sci. Technol., 2008, 42, 2451-2456.

18 L. P. Liang, W. J. Yang, X. H. Guan, J. L. Li, Z. J. Xu, J. Wu, Y. Y. Huang and X. Z. Zhang, Water Res., 2013, 47, 58465855.

19 L. P. Liang, W. Sun, X. H. Guan, Y. Y. Huang, W. Y. Choi, H. L. Bao, L. N. Li and Z. Jiang, Water Res., 2014, 49, 371-380.

20 C. Wang and W. Zhang, Environ. Sci. Technol., 1997, 31, 2154-2156.

21 S. J. Yu, L. Yin, H. W. Pang, Y. H. Wu, X. X. Wang, P. Zhang, B. W. Hu, Z. S. Chen and X. K. Wang, Chem. Eng. J., 2018, 352, 360-370.

22 S. J. Yu, X. X. Wang, Y. F. Liu, Z. S. Chen, Y. H. Wu, Y. Liu, H. W. Pang, G. Song, J. R. Chen and X. K. Wang, Chem. Eng. J., 2019, 365, 51-59.

23 C. Lee, J. Y. Kim, W. I. Lee, K. L. Nelson, J. Yoon and D. L. Sedlak, Environ. Sci. Technol., 2008, 42, 4927-4933.

24 X. Wang, H. L. Dong, Q. Zeng, Q. Y. Xia, L. M. Zhang and Z. Q. Zhou, Environ. Sci. Technol., 2017, 51, 7639-7647.

25 Y. S. El-Temsah and E. J. Joner, Chemosphere, 2012, 89, 7682.

26 L. Zhou, W. Zhuang, X. Wang, K. Yu, S. Yang and S. Xia, Water Res., 2017, 111, 140-146.

27 S. J. Yu, Y. Liu, Y. J. Ai, X. X. Wang, R. Zhang, Z. S. Chen, Z. Chen, G. X. Zhao and X. K. Wang, Environ. Pollut., 2018, 242, 1-11.

28 H. W. Pang, Z. F. Diao, X. X. Wang, Y. Ma, S. J. Yu, H. T. Zhu, Z. S. Chen, B. W. Hu, J. R. Chen and X. K. Wang, Chem. Eng. J., 2019, 366, 368-377.

29 Y. H. Huang and T. C. Zhang, Water Res., 2005, 39, 17511760.

30 L. J. Xu and J. K. Wang, J. Hazard. Mater., 2011, 186, 256-264. 31 Y. Xie, H. Dong, G. Zeng, L. Zhang, Y. Cheng, K. Hou, Z. Jiang, C. Zhang and J. Deng, J. Hazard. Mater., 2017, 338, 306-312.

32 X. H. Guan, Y. K. Sun, H. J. Qin, J. X. Li, I. M. C. Lo, D. He and H. R. Dong, Water Res., 2015, 75, 224-248. 